\title{
Excavating in breccia: new methods developed at the Benzú rockshelter
}

\author{
S. Domínguez-Bella ${ }^{1}$, J. Ramos ${ }^{2}$, D. Bernal ${ }^{2}$, E. Vijande ${ }^{2}$, \\ J.J. Cantillo ${ }^{2}$, A. Cabral ${ }^{2}$, M. Pérez ${ }^{3} \&$ A. Barrena ${ }^{2}$
}

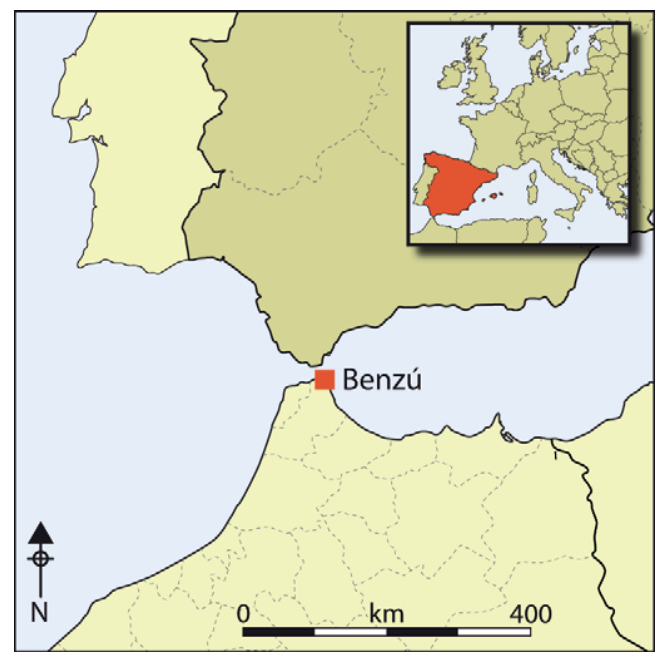

Excavators examining breccia deposits are faced with the prospect of extracting finds from a material akin to concrete. Nevertheless such deposits are sometimes the only witness of early Palaeolithic occupation. Our inventive authors put aside the hammers, acids and explosives of earlier days, and used quarry techniques to cut the breccia into small blocks, which they then freed from their finds in the laboratory, using tools developed in palaeontology. As a result, they gathered a huge harvest of stone tools, bones and shells. It all goes to show that archaeological excavation is an exercise of infinite variety: to every problem, its solution; to every terrain, its method.

Keywords: North Africa, Ceuta, Benzú rockshelter, Palaeolithic, excavation method, breccia

\section{Introduction}

Breccia is a densely consolidated material consisting of angular fragments of rock cemented in a matrix (Loucks 1999; Loucks \& Mescher 2001). Sedimentary breccias typically form within and on the talus of limestone caves as a result of water flow, and may be regarded as lithified colluvium. They can continue to form after human occupation, and thus may contain artefacts. The problem of excavating in breccia is basically one of defining an archaeological sequence in a deposit that resembles concrete.

Breccia sites are relatively abundant in the world (Latham 1999), occurring in karst environments associated with caves and rockshelters. Well known examples include Limeworks Cave, Makapansgat, South Africa (Hill \& Forti 1997), Zhoudoudian, China

1 Ciencias de la Tierra, Facultad de Ciencias, Universidad de Cádiz, Campus Rio San Pedro, Av. Republica Saharauhi s/n, Puerto Real, Cádiz 11510, Spain (Author for correspondence, email: salvador.dominguez@uca.es)

2 Departmento de Historia, Geografía y Filosofia, Facultad de Filosofia y Letras, Universidad de Cádiz, Av. Dr. Gómez Ulla, s/n, Cádiz 11001, Spain

3 Area de Prehistoria, Facultat de Filosofia i Lletras, Universitat Autònoma de Barcelona, Edifici B Campus de la UAB, Cerdanyola del Vallées, Barcelona 08193, Spain 


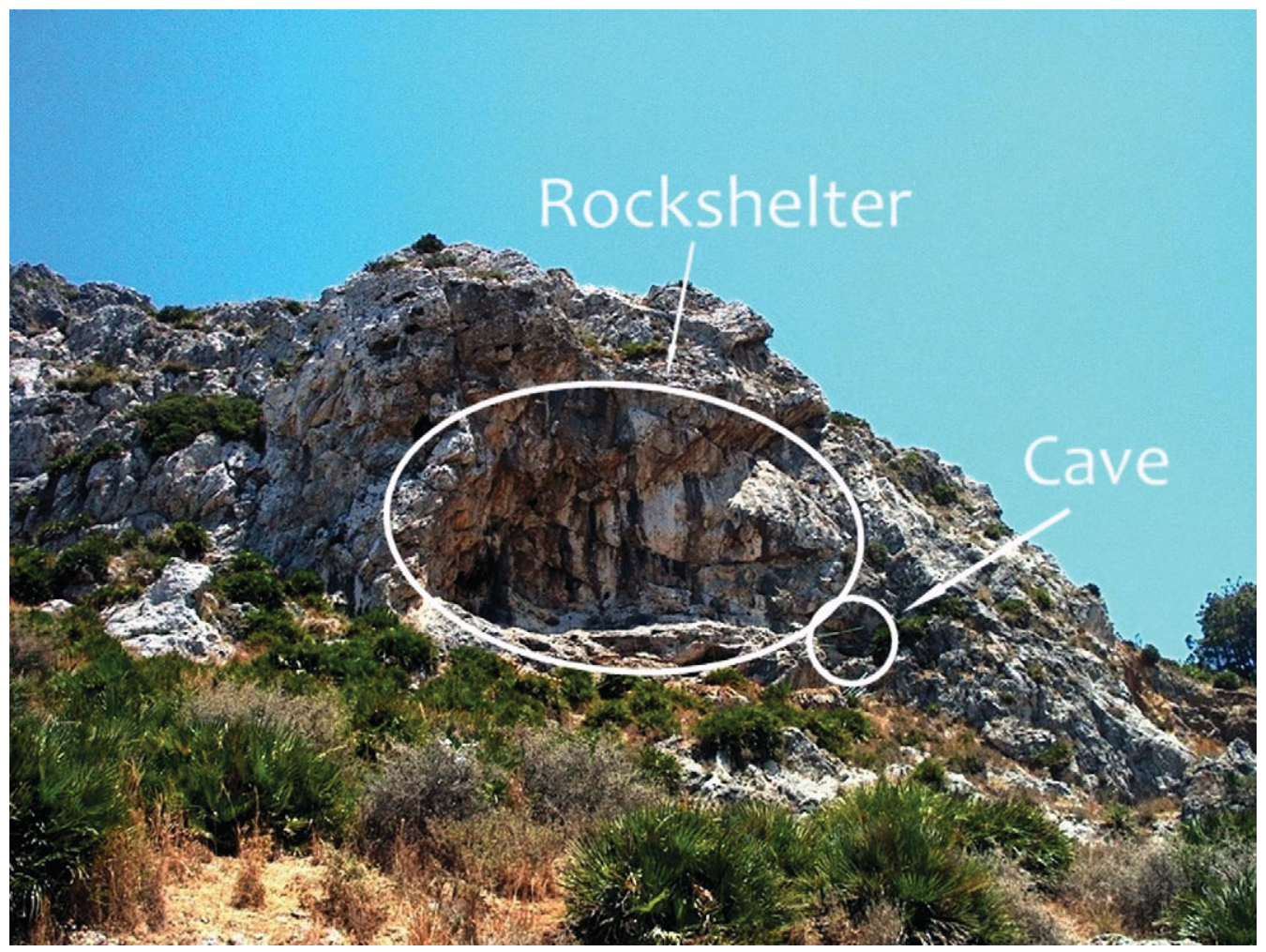

Figure 1. View of Benzú rockshelter and cave.

(Wu \& Dong 1985) and Red Barns, Portchester, Hampshire, UK (Wenban-Smith et al. 2000). At Grotta di Porto Infreschi, Camerota (Italy), a series of marine conglomerates containing Spondylus (probably of the Tyrrhenian geological stage) was succeeded by alternating levels of red clay, breccias, pyroclasts and stalagmitic crusts, sealed at the top by colluvial deposits and rock falls with a Mousterian industry (Bachechi 1989-1990). Examples from the Iberian peninsula include Gibraltar-Beefsteak Cave (Giles et al. 2007), Rosia Bay breccia (White 1913; Finlayson et al. 2006), Tajo de Doña Ana, Alfarnatejo (Ramos et al. 19951996) and Cueva del Ángel, Lucena, Córdoba (Barroso et al. 2011), in Andalucía, and Figueira Brava Cave (Portugal), a rockshelter of the Middle Palaeolithic (Upper Mousterian), dated to between 30 and $31 \mathrm{ka}$ (Antunes 1990-91; Antunes \& Cardoso 1992).

Excavators have been obliged to work round the densely cemented breccias, or attack them with heavy machinery and even with low-power explosives. In such cases, the recovery of archaeological material has naturally been poor. In this paper, we describe a new approach to the problem, developed during research at the rockshelter of Benzú.

\section{The Benzú rockshelter}

The archaeological site of Benzú is situated on the coast of North Africa, on the south side of the Strait of Gibraltar in the autonomous Spanish city of Ceuta. It is located about $230 \mathrm{~m}$ from the present shoreline (Figure 1). The Palaeolithic rockshelter, discovered in 2001 (Bernal (C) Antiquity Publications Ltd. 


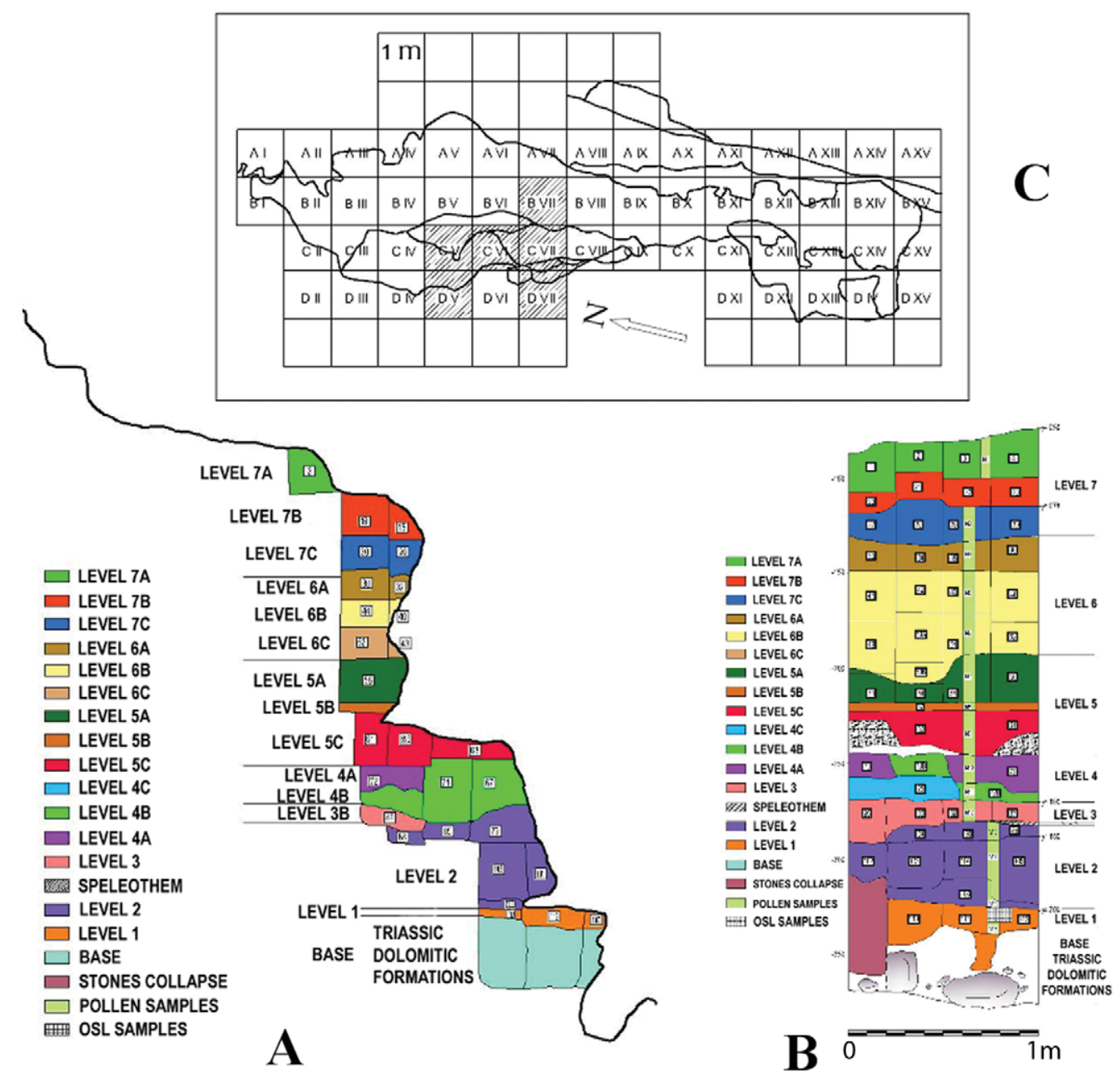

Figure 2. Excavations at Benzú: A) schematic section of the breccia front, vertical section of BVII-CVII-DVII squares, seen from the north; B) vertical section of the breccia levels in BVII-CVII-DVII squares, seen from the east; $C)$ grid plan of the rockshelter breccia (the excavated sections are shaded). Vertical profiles are shown in $(A)$ and $(B)$.

2001), contains an archaeological deposit mostly consisting of limestone breccia, of a high degree of compactness and hardness. The shelter was formed through erosion before Isotope Stage 9 and any human occupation (Abad et al. 2007). It may have lost its overhanging cornice during the Quaternary (Durán 2003; Ramos \& Bernal 2006; Ramos et al. 2008). Adhering to the rock wall of Triassic dolomite is a deposit of highly consolidated calcareous breccias. This was defined in plan and section (Figure 2), and subsequently resolved into ten stratified levels (Table 1). Geological studies of the sedimentation (Durán 2003) show that stratigraphic levels 1 to 7 contain evidence for early human occupation. This took the form of a Mode III-Mousterian knapped stone industry, with chronologies ranging from 70-250 ka (Durán 2004; Ramos et al. 2008), and include indications of marine resource exploitation (Ramos et al. 2011). Lithics, animal bone and shells (malacofauna) all survive well within the breccia (Figure 3).

(C) Antiquity Publications Ltd. 
Table 1. Stratigraphic sequence, types of sediments and chronology of the Benzú rockshelter (after Ramos et al. 2008).

\begin{tabular}{|c|c|c|c|}
\hline Strata & Type of sediment & Chronology & Observations \\
\hline 10 & Upper speleothem & $(\mathrm{Th} / \mathrm{U}) \mathrm{IGM}: \pm 70 \mathrm{ka}$ & Seals the whole sequence \\
\hline 9 & Breccia with clasts & & \\
\hline 8 & Micrite & & \\
\hline 7 & $\begin{array}{l}\text { Breccia cemented with } \\
\text { dolomite blocks }\end{array}$ & & \\
\hline 6 & Micritic mud & & \\
\hline 5 & Breccia of sands and muds & $\begin{array}{l}\text { (OSL) Shfd020136: } \\
168 \pm 11 \mathrm{ka}\end{array}$ & $\begin{array}{l}\text { OSL datation of the } \\
\text { upper part of the strata }\end{array}$ \\
\hline 4 & Breccia of clast and muds & & \\
\hline $3 b$ & Speleothem & (Th/U) IGM: $173 \pm 10 \mathrm{ka}$ & Thin speleothem \\
\hline 3 & Micritic mud & & \\
\hline 2 & Breccia of clast and muds & $\begin{array}{l}\text { (OSL) Shfd 020135: } \\
254 \pm 17 \mathrm{ka}\end{array}$ & $\begin{array}{l}\text { OSL datation of the } \\
\text { upper part of the strata }\end{array}$ \\
\hline 1 & Breccia & & \\
\hline 0 & Rock (dolomite) & & \\
\hline
\end{tabular}

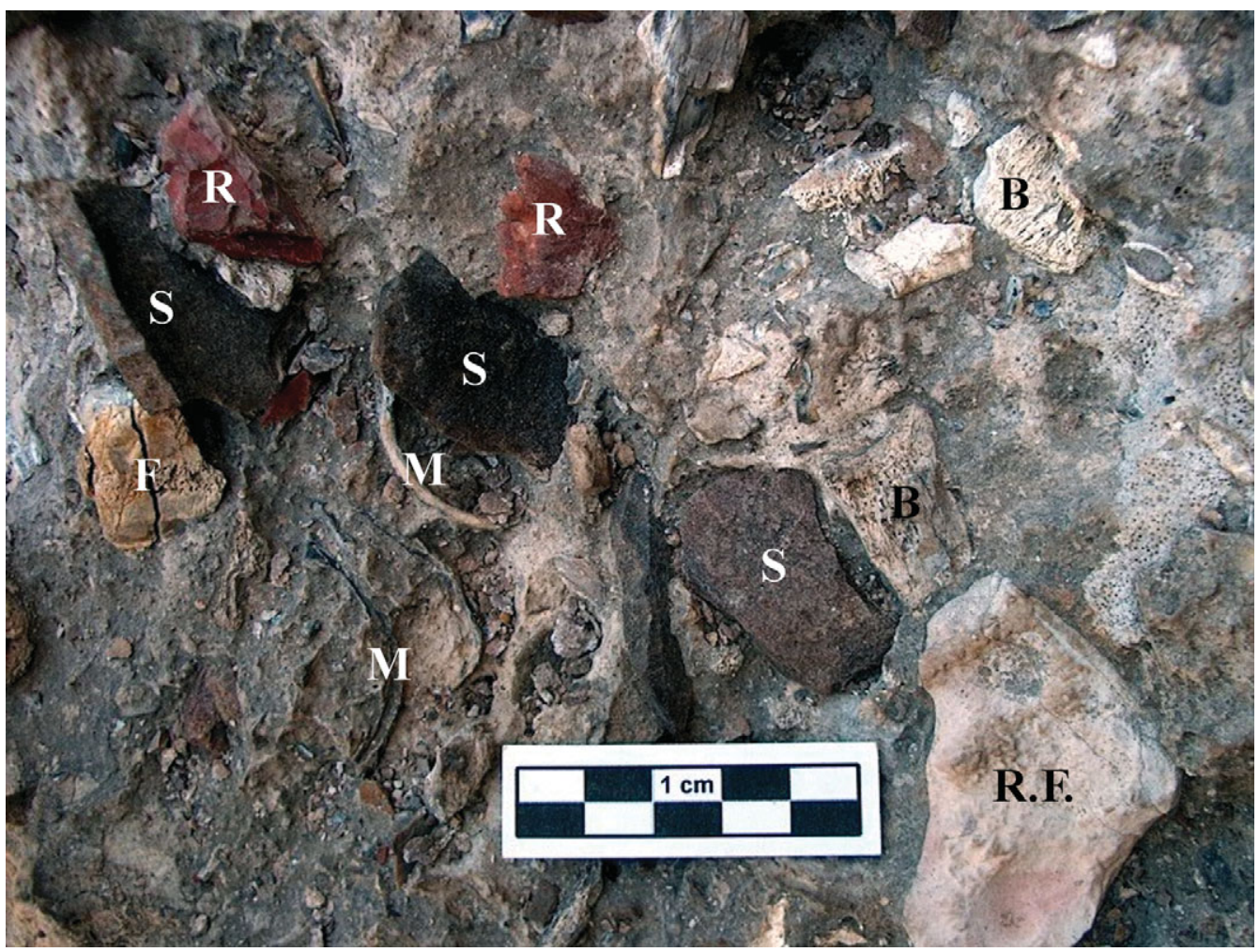

Figure 3. Aspect of the lithic industry and faunal remains in the breccia $(B=$ bone; $R=$ radiolarite; $F=$ fint; $S=$ sandstone; $R F=$ rock fragments; $M=$ malacofauna).

(C) Antiquity Publications Ltd. 


\section{S. Dominguez-Bella et al.}

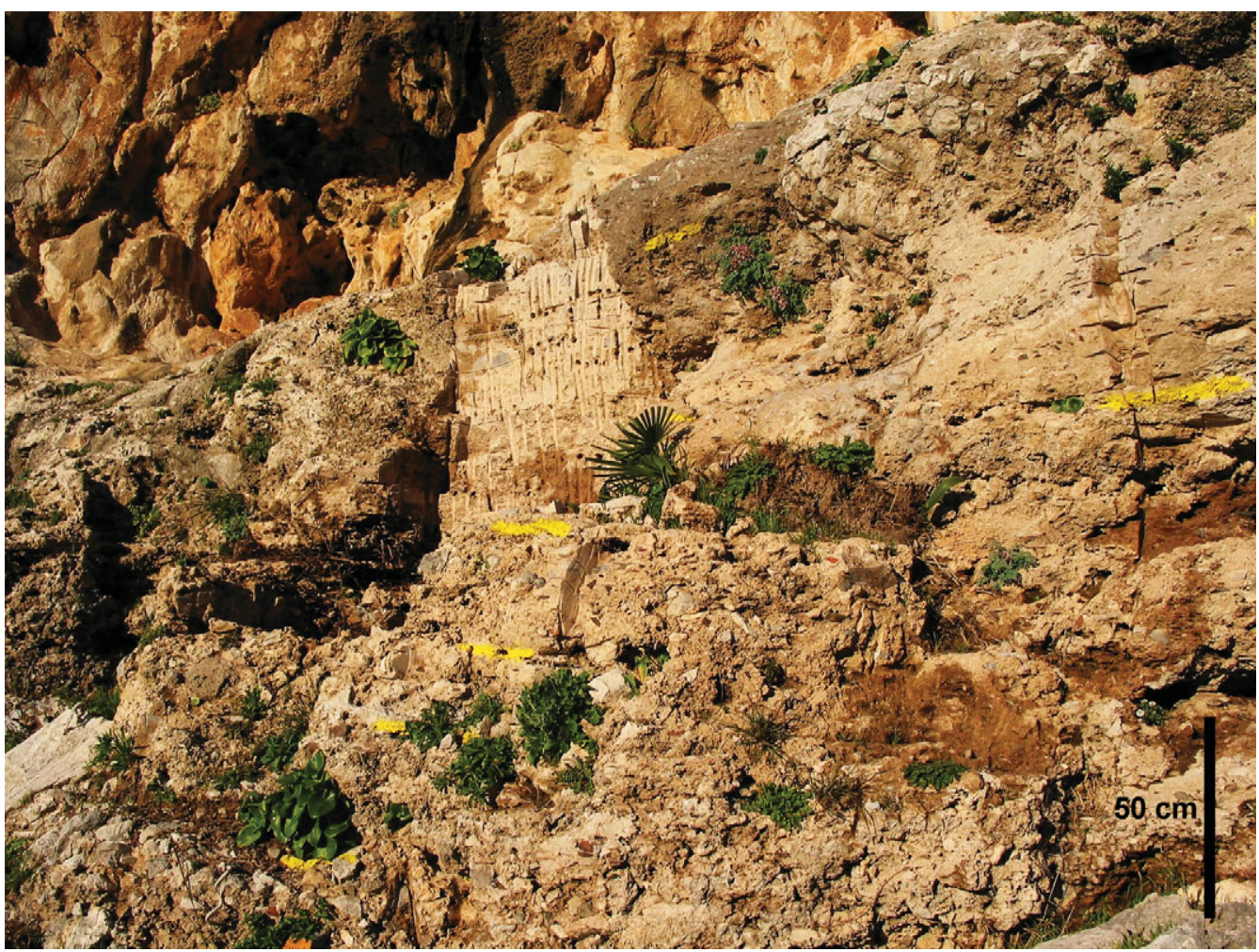

Figure 4. The front of the breccia deposit, showing the area of extracted blocks in June 2003.

\section{Methodology}

The rockshelter measured $15.52 \times 6.20 \mathrm{~m}$, and the top surface of the breccia deposit occupied an area of $61.2 \mathrm{~m}^{2}$ in plan (Figure 2C). Our methodology was developed over six seasons between 2002 and 2008. In 2002, the upper level of the deposit (Stratum 7) was defined (Ramos et al. 2003), and a $25 \mathrm{~cm}$ grid laid out on its upper surface. From this surface we first attempted vertical excavation, using chisels and hammers. However, these tools also fractured the siliceous minerals and rocks, such as flint, radiolarites and sandstones that constituted the artefacts (Chamorro et al. 2003; Chamorro 2004; Domínguez-Bella 2004; Domínguez-Bella et al. 2006). We then applied hydrochloric or acetic acid in an attempt to loosen or dissolve the calcium carbonate $\left(\mathrm{CaCO}_{3}\right)$ of the breccia. This was not only very slow (and dangerous for the health of the excavators), but also affected the surface of the lithics, impairing subsequent chemical or wear analysis. The acid also attacked remains of organic origin, such as malacofauna (mainly composed of $\mathrm{CaCO}_{3}$ ) and the skeletal remains of animals or humans.

Following this frustrating experience, we developed a different methodology inspired by methods used for the extraction of stone in quarries and the extraction of fossils from stone. The new strategy was to extract the deposit in small blocks (Stage 1) and then disaggregate them in the laboratory (Stage 2). We began the 2003 campaign (Figure 4) equipped with

(C) Antiquity Publications Ltd. 

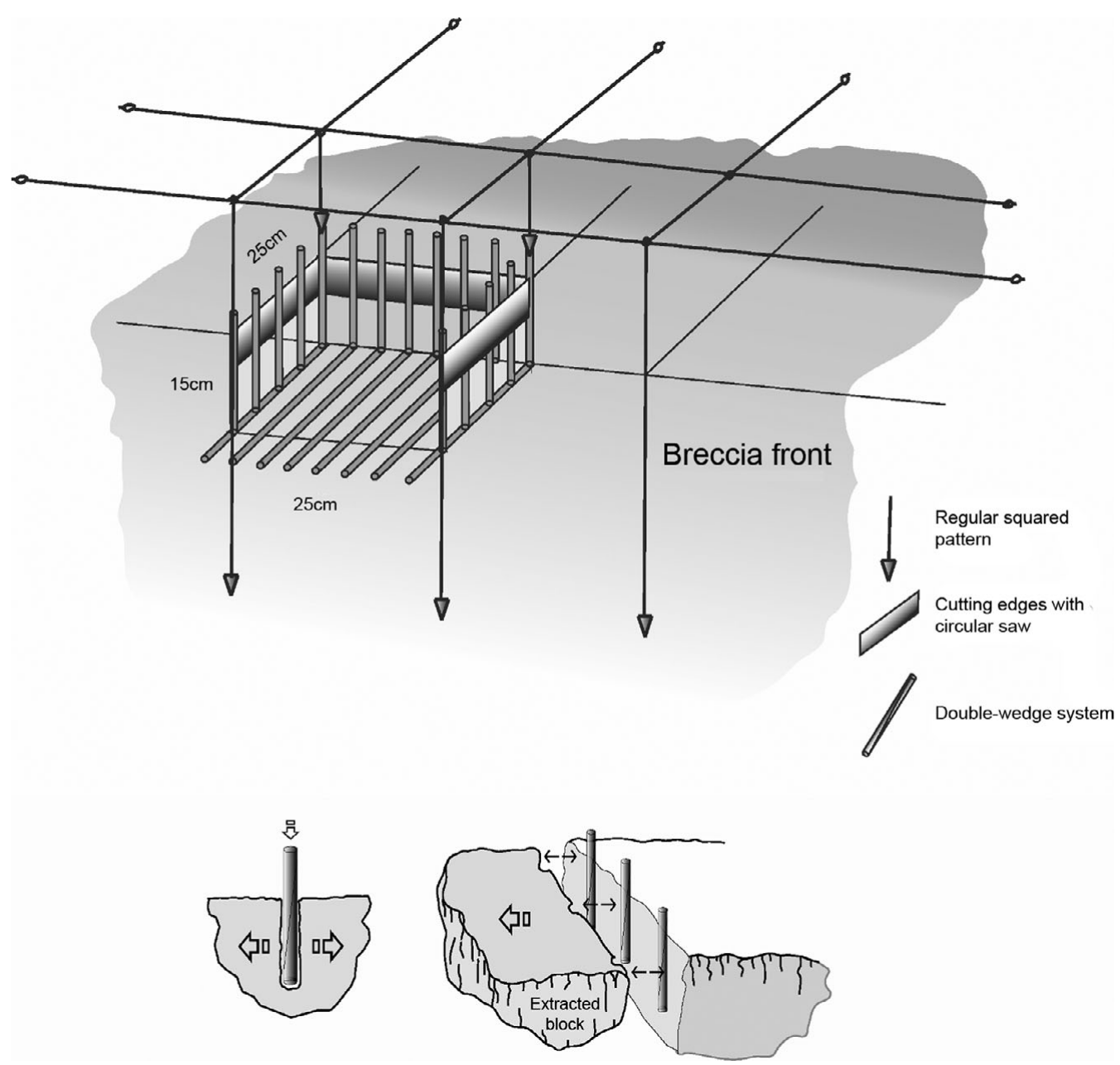

Figure 5. Stage 1: extraction of the blocks. Rows of holes are drilled on four sides and beneath, and the block extracted using double-wedges hammered into the holes.

newly-purchased power drills for stone with bits of $20 \mathrm{~mm}$ diameter, a portable circular power saw with diamond blades of $20 \mathrm{~cm}$, steel wedges, and the traditional hammers and chisels.

\section{Stage 1}

Blocks $25 \times 25 \times 15 \mathrm{~cm}$ were marked out and an initial cut made along all four sides and beneath (from the side) using a diamond tipped circular saw, capable of penetrating about $7 \mathrm{~cm}$ into the breccia, with a blade thickness of $4 \mathrm{~mm}$. Rows of holes were then drilled with a tungsten carbide $15 \mathrm{~mm}$ diameter bit along the same axes, to the full depth required (Figures 5 \& 6). Wedges and double-wedges were inserted in these holes, and hammered until the

(C) Antiquity Publications Ltd. 


\section{S. Dominguez-Bella et al.}

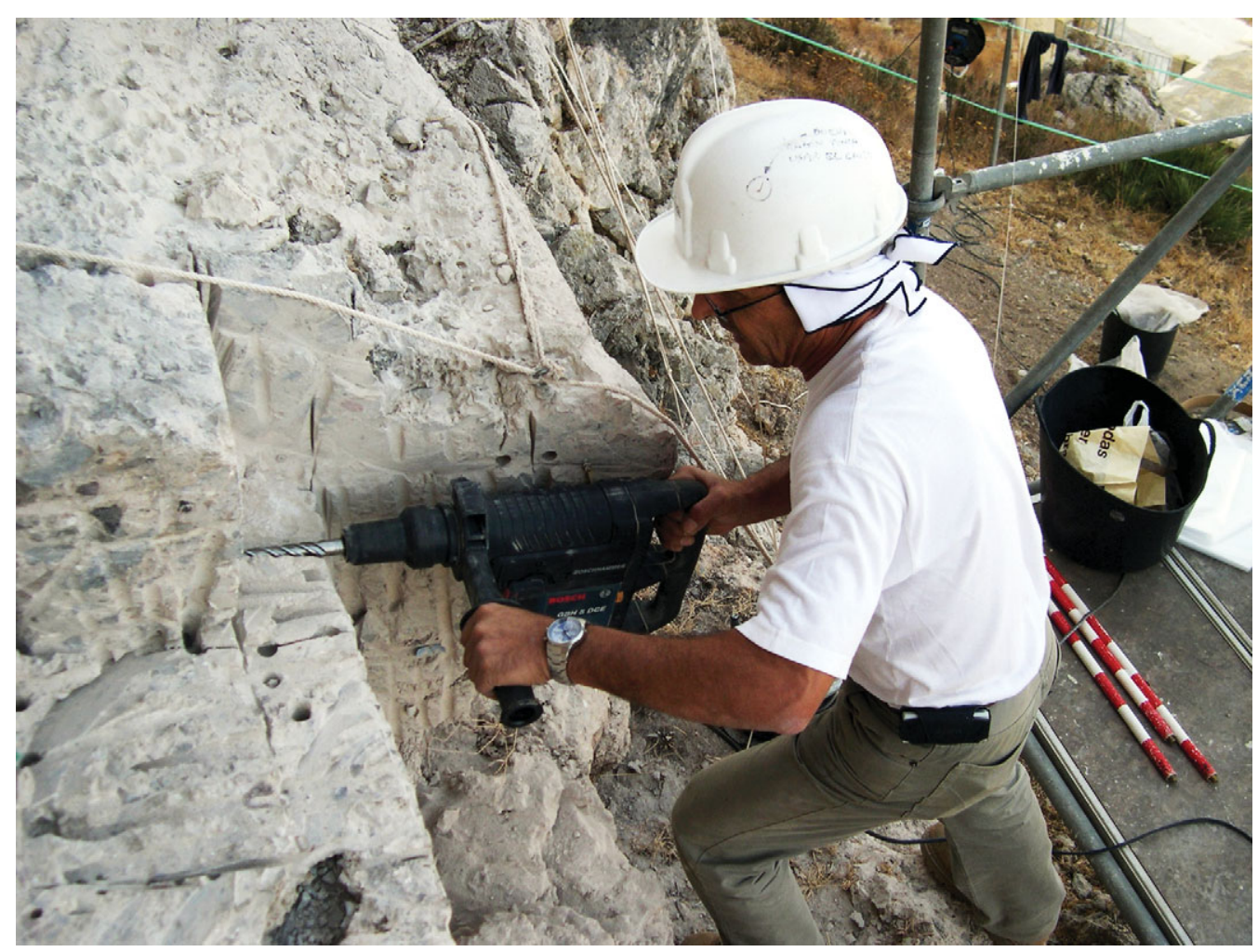

Figure 6. Drilling the holes.

block fractured along the cut lines (Figure 7). Once cut free, the blocks were labelled with their grid co-ordinates and orientation and packaged for shipment to the laboratory.

The same method was then applied to stratum 6 . Strata 5 and 4 proved more workable than the others, and could be excavated with standard procedures (small trowels and brushes). From the third excavation campaign (2004) the method was slightly modified, applying a new system of wedges and double-wedges created by our collaborator A. García Cañizares, based on ideas discussed with the group speleologist, A. Luque. Strata 3, 2 and 1 were excavated, reaching the floor of dolomite rock, which we believe represents the bedrock of the original cavity in this area of the rockshelter. Thus the full depth of the stratigraphic sequence was retrieved in blocks (Figure 8, see also Figure 4).

\section{Stage 2}

In the laboratory each block was carefully unpacked and disintegrated to recover the assemblages locked inside them. The coarse fragments of breccia were removed using hammers and conventional small chisels (Figure 9), releasing material containing bone, shell and artefacts. These were then cleaned of breccia with Chicago Pneumatic ${ }^{\circledR}$ compressed air tools (Figure 10), as used in palaeontology. We used different types of percussion tips and tools such as microdrills $\left(\right.$ Dremel $^{\circledR}$ ), always working under magnifying glass visors. Faunal

(C) Antiquity Publications Ltd. 

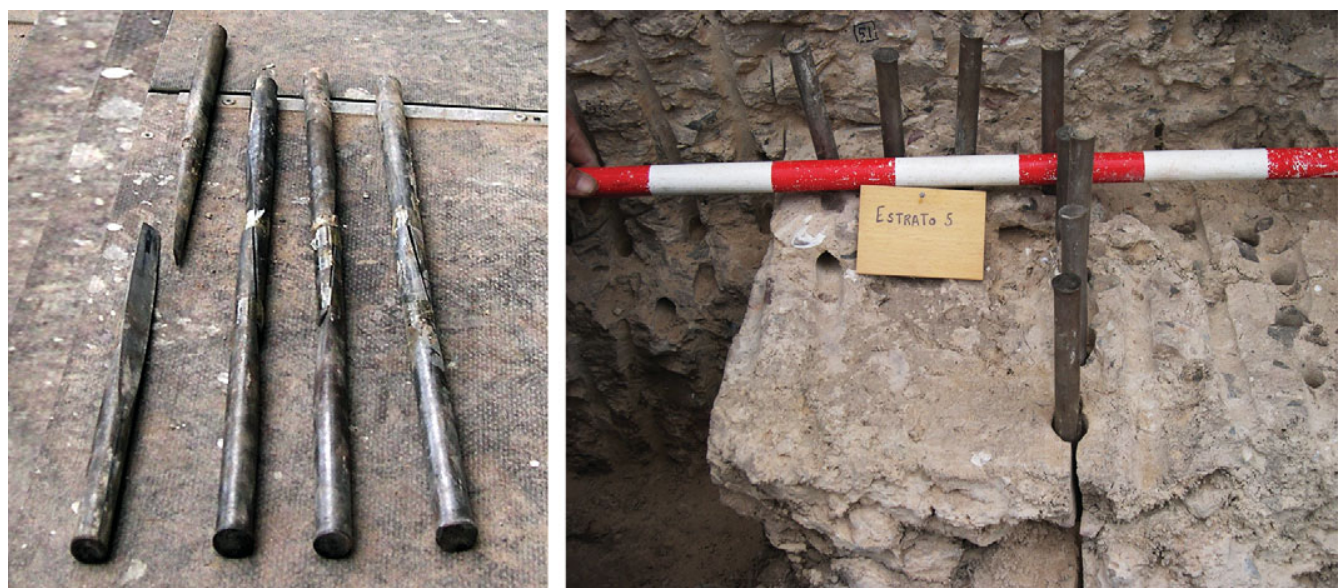

Figure 7. The double-wedges (left) inserted into the drilled holes (right).

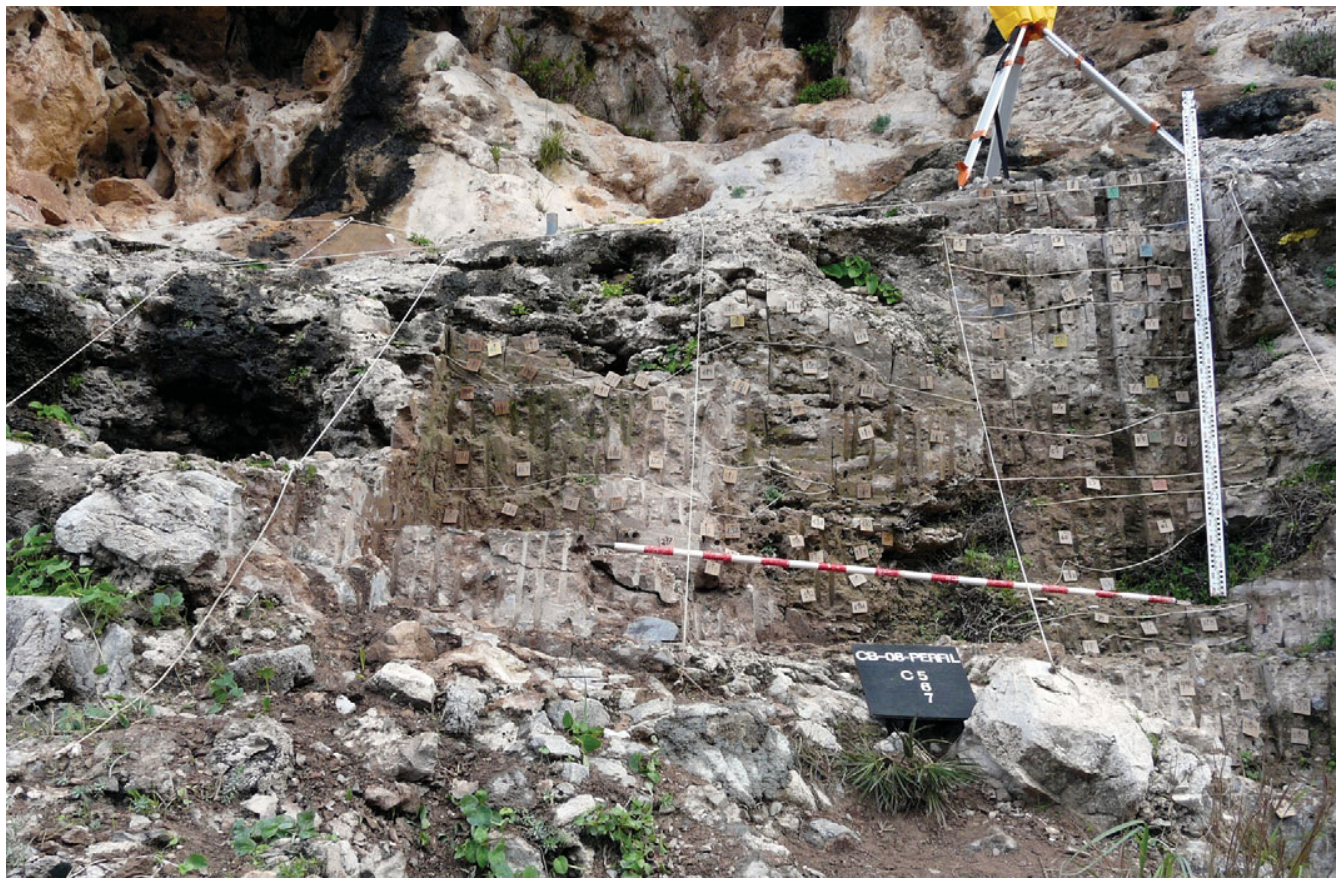

Figure 8. Vertical surface of the breccia deposit, after the removal of several layers of blocks.

remains were consolidated with Primal, diluted to 50 per cent. Overall, the procedure resulted in a suite of assemblages related to a stratified sequence determined by the original position of the block.

(C) Antiquity Publications Ltd. 


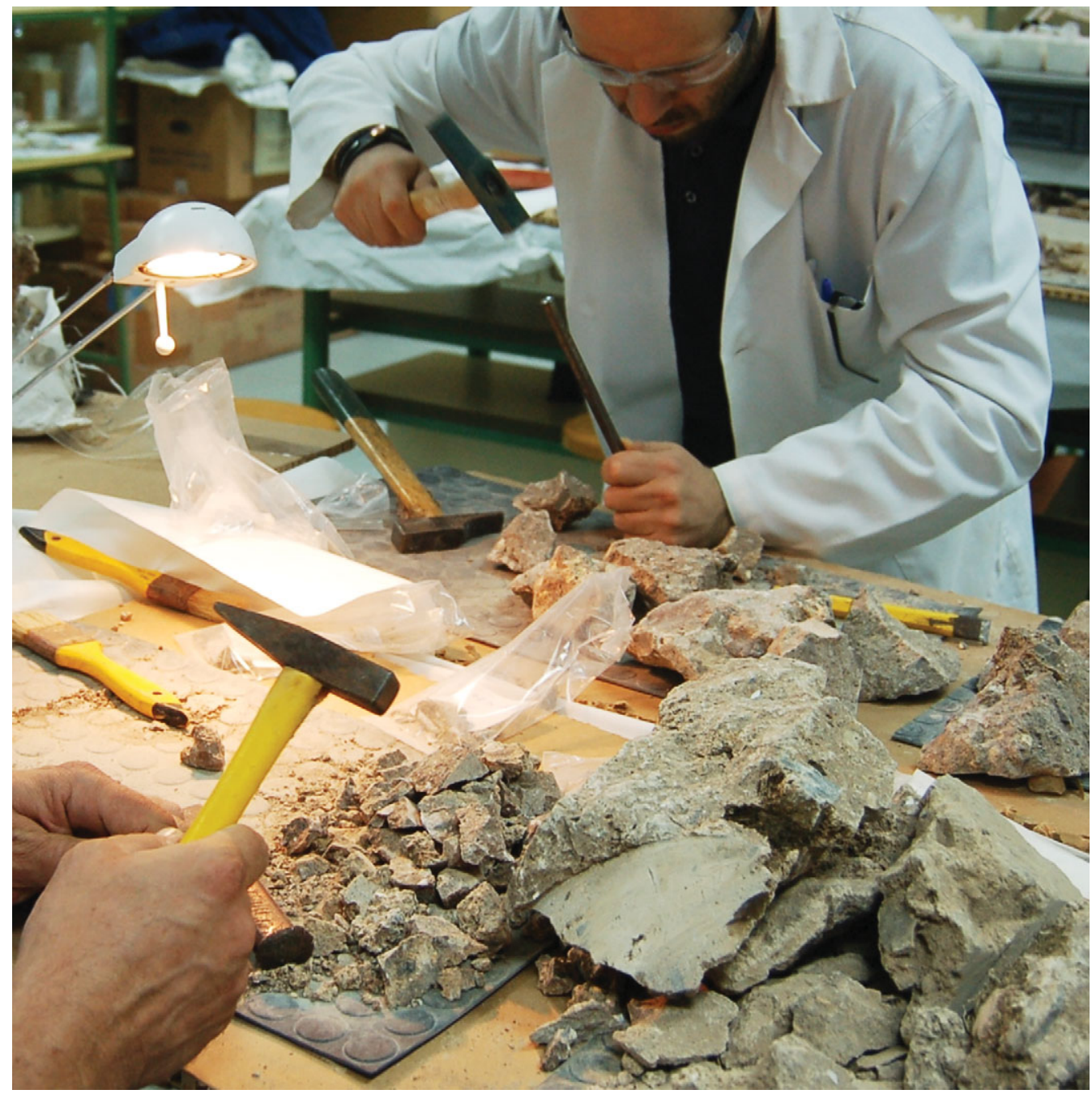

Figure 9. Stage 2: in the laboratory. Small chisels are used to break up the block and separate the visible finds from the breccia.

\section{Critique}

The volume of excavated rock lost or destroyed by this method largely corresponded to the volume of holes made in the breccia to accommodate the wedges and of the cuts performed with the circular saw. This was calculated to be up to 4.41 per cent of the recovered block, which is considered acceptable, especially given that this type of material has often not been excavated at all.

However, the method has not succeeded in recording the presence of structures or addressing the horizontal use of space, which would throw more light on the organisation of the human groups and their activities. This does present some problems, particularly due to the survival of breccia deposits themselves, which have often disappeared due to erosion

(C) Antiquity Publications Ltd. 


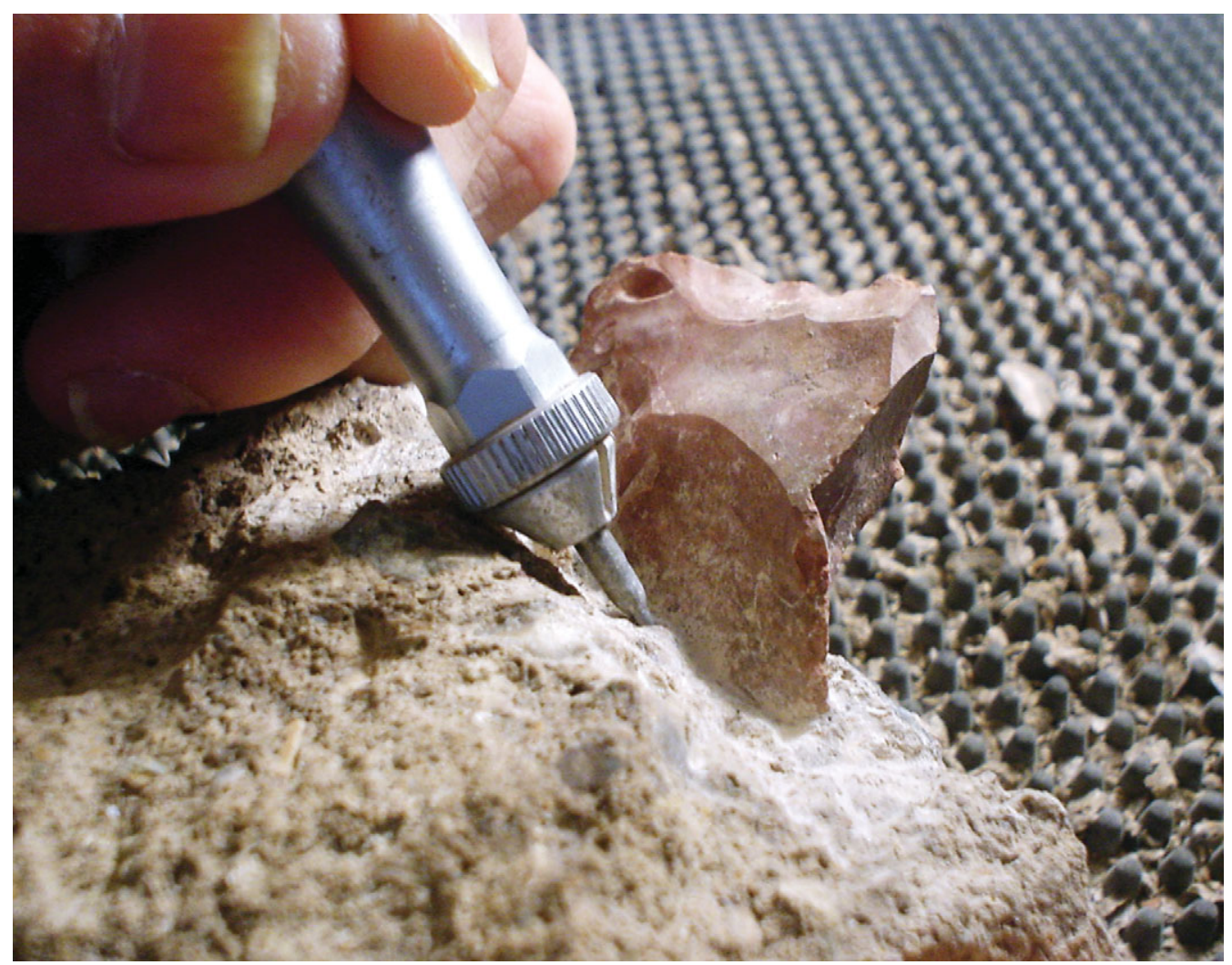

Figure 10. Using micro-percussion tools (Chicago Pneumatic ${ }^{\circledR}$ ) for small-scale disintegration and recovery of lithic and faunal remains.

in recent millennia. The recovery of botanical remains is also a challenge. A comparison can be drawn with the better-defined Neolithic occupation excavated in a cave immediately adjacent to the rockshelter (Vijande et al. 2008). Here the sandy sediment permitted more familiar stratigraphic excavation and three-dimensional finds plotting (Vijande 2011).

\section{Conclusion}

In spite of the intractable nature of the breccia deposit, more than 50000 finds were recovered in sequence, informing the economy and society of hunter-gatherer groups through the Middle and Upper Pleistocene. Studies are currently being carried out on a wide range of archaeological materials (microvertebrates, malacofauna, large vertebrates, pollen, birds and rodents), including dating using TSL and U-Th techniques (Ramos et al. 2008, 2011). This rich assemblage shows that the methods applied are effective and may have applications at other archaeological sites in different parts of the world.

\section{Acknowledgements}

We acknowledge the collaboration of the Government of Ceuta and the University of Cádiz, as well as colleagues from the Instituto de Estudios Ceutíes and the Tetouan University. Authorisation for the excavations was given

(C) Antiquity Publications Ltd. 


\section{S. Domínguez-Bella et al.}

by the Spanish Ministry of Culture. We also acknowledge the financial support of the excavation works of the Government of Ceuta and appreciate the support offered by the Instituto de Estudios Ceutíes. In 2003 we used the facilities of a public school, made available by the Autonomous City of Ceuta and in 2004 and 2005 we were hosted by the Museum of the Royal Walls of Ceuta. From 2006, laboratory work was done in different units of the University of Cádiz, including the Laboratory of Archaeology and Prehistory. Finally, we thank two reviewers for their comments and suggestions, and Ms Ana Durante, Dr Emilio Marquez and Prof Martin Carver for their editorial assistance and enriching comments.

\section{References}

AbAd, M., L.M. CÁCERES, J. RodrígueZ-Vidal, F. Ruiz, N. López-GonzÁlez, S. Chamorro, D. BERNAL \& J. RAMOs. 2007. Rasgos morfológicos y bioerosivos en un alto nivel marino del Pleistoceno Medio: el abrigo arqueológico de la Cabililla de Benzú (Ceuta), in J. Lario Gómez \& P.G. Silva (ed.) XII Reunión Nacional de Cuaternario: 69-70. Madrid: Universidad Politécnica de Madrid.

ANTunes, M.T. 1990-1991. O Homem da Gruta da Figueira Brava (ca. 30000 BP). Contexto ecológico, alimentação, canibalismo. Memórias da Academia das Ciências de Lisboa, Classe de Ciências 31: 487-536.

Antunes, M.T. \& J.L Cardoso. 1992. Elefantes cuaternarios en Portugal: nuevos datos. Ciências da Terra 11: 17-37.

BACHECHI, L. 1989-1990. L'industria litica della Grotta di S. Maria a Porto Infreschi (Marina di Camerota, Salerno). Rivista di Scienze Preistoriche 42: 289-303.

Barroso Ruiz, C., D. Botella Ortega, M. Caparrós, A.M. Moigne, V. Celiberti, A. Testu, D. Barsky, O. NotTer, J.A. Riquelme Cantal, M. Pozo Rodríguez, M.I. Carretero León, G. Monge Gomez, S. Khatib, T. Saos, S. Gregoire, S. Bailón, J.A. García Solano, A.L. Cabral Mesa, A. Djerrab, I.G. Hedley, S. Abdessadok, G. Batalla llasat, N. Astier, L. Bertin, N. Boulbes, D. Cauche, A. Filoux, C. Hanquet, C. Milizia, J. Moutoussamy, E. Rossoni, L. Verdú Bermejo \& H. DE Lumley. 2011. The Cueva del Angel (Lucena, Spain): an Acheulean hunters habitat in the south of the Iberian peninsula. Quaternary International 243: 105-26.

Bernal Casasola, D. 2001. Carta arqueológica terrestre del término municipal de Ceuta (Universidad de Cádiz-Ciudad Autónoma de Ceuta). Original held at Consejería de Educación y Cultura de la Ciudad Autónoma de Ceuta.

Chamorro, S. 2004. Marco geológico del Abrigo y Cueva de Benzú, in J. Ramos, D. Bernal \& V. Castañeda (ed.) Investigación interdisciplinar en Humanidades. Excavaciones arqueológicas en el yacimiento de Benzú (Ceuta): 145-51. Ceuta: Universidad de Granada.
Chamorro, S., S. Domínguez-Bella \& F. Pereila. 2003. Geología del yacimiento de Benzú. Análisis arqueométrico de la industria lítica y las materias primas minerales, in J. Ramos, D. Bernal, V. Castañeda (ed.) El Abrigo y la Cueva de Benzú en la prehistoria de Ceuta: aproximación al estudio de las sociedades cazadoras-recolectoras y tribales comunitarias en el ambito norteafricano del Estrecho de Gibraltar: 169-205. Cádiz: Universidad de Cádiz.

Domínguez-Bella, S. 2004. Arqueometría, materias primas minerales, captación, distribución y consumo de recursos líticos en el yacimiento de Benzú, in J. Ramos, D. Bernal \& V. Castañeda (ed.) Investigación interdisciplinar en Humanidades. Excavaciones arqueológicas en el yacimiento de Benzú (Ceuta): 153-59. Ceuta: Universidad de Granada.

Domínguez-Bella, S., S. Chamorro, J. Ramos \& D. BERNAL. 2006. Materias primas minerales y geología en el entorno del Abrigo y la Cueva de Benzú (Ceuta), in G. Martínez Fernández, A. Morgado Rodríguez \& J.A. Afonso Marrero (ed.) Sociedades prehistóricas, recursos abióticos y territorio: actas de la III Reunión de trabajo sobre aprovisionamiento de recursos abióticos en la Prehistoria: 119-33. Granada: Fundación Ibn al-Jatib de Estudios de Cooperación Cultural.

DURÁN, J.J. 2003. Informe geológico del Abrigo de Benzú, in J.Ramos, D. Bernal, V. Castañeda (ed.) El Abrigo y la Cueva de Benzú en la prehistoria de Ceuta: aproximación al estudio de las sociedades cazadoras-recolectoras y tribales comunitarias en el ambito norteafricano del Estrecho de Gibraltar: 263-66. Cádiz: Universidad de Cádiz.

- 2004. Estudio de los sedimentos carbonáticos asociados a cavidades cársticas. Métodos de datación, geocronología absoluta y análisis de isótopos estables, in J. Ramos, D. Bernal, V. Castañeda (ed.) Investigación interdisciplinar en Humanidades. Excavaciones arqueológicas en el yacimiento de Benzú (Ceuta): 125-31. Ceuta: Universidad de Granada. 


\section{Excavating in breccia}

Finlayson, C., F. Giles, J. Rodríguez-Vidal, D.A. Fa. J.M. Gutiérrez, A. Santiago, G. Finlayson, E. Allué, J. Baena, I. Cáceres, J.S Carrión, Y. Fernández Jalvo, C.P. Gleed-Owen, F.J. JimÉNEZ-EsPejo, P. LÓPEZ, J.A. LÓPEZ SÁEZ, J.A. Riquelme, A. SÁnchez Marco, F. Giles GuZmán, K. Brown, N. Fuentes, C.A. Valarino, A. Villalpando, C.B. Stringer, F. Martínez-Ruiz $\&$ T. SAKAMOTO. 2006. Late survival of Neanderthals at the southernmost extreme of Europe. Nature 443(7113): 850-53.

Giles, F., C. Finlayson, G. Finlayson, D. Fa, J. RODrígueZ-VIDAL, L.M. CÁCERES, A. Martínez-Aguirre, A. Santiago \& J.M. GuTiérRez LÓPEZ. 2007. Industria del Paleolítico Medio en Beefsteak Cave (Gibraltar): implicaciones paleoambientales. Geogaceta, 43: 131-34.

Hill, C.A. \& P. ForTI. 1997. Cave minerals of the world. Huntsville (AL): National Speleological Society.

LATHAM, A.G. 1999. Cave breccias and archaeological sites. Capra 1. Available at: http://capra.group. shef.ac.uk/1/breccia.html (2 April 2012).

LOUCKs, R.G. 1999. Paleocave carbonate reservoirs: origins, burial-depth modifications, spatial complexity, and reservoir implications. American Association of Petroleum Geologists Bulletin 83: 1795-1834.

Loucks, R.G. \& P.K. Mescher. 2001. Paleocave facies classification and associated pore types. Paper presented at the AAPG Southwest Section Annual Meeting, 11-13 March 2001, Dallas, Texas.

Ramos, J. \& D. Bernal (ed.). 2006. El proyecto Benzú. 250.000 años de historia en la orilla africana del círculo del Estrecho: 30 preguntas y 10 opiniones. Cádiz: Universidad de Cádiz.

Ramos, J., J.J. Durán, S. Domínguez-Bella, V. Castañeda, N. Herrero, P. Cantalejo, A. Recio, I. Caceres, D. Morata, M.M Espejo \& E. MARTín. 1995-1996. El abrigo del Tajo de Doña Ana I (Alfarnatejo, Málaga). Un asentamiento de cazadores del Pleistoceno Superior. Avance geomorfológico, petrológico, tecnológico y faunístico. Mainake 17-18: 5-26.
Ramos, J., D. Bernal \& V. Castañeda (ed.). 2003. El Abrigo y la Cueva de Benzú en la prehistoria de Ceuta. Cádiz: Universidad de Cádiz.

Ramos, J., D. Bernal, S. Domínguez-Bella, D. Calado, B. Ruiz, M.J. Gil, I. Clemente, J.J. Durán, E. Vijande \& S. Chamorro. 2008. The Benzú rockshelter: a Middle Palaeolithic site on the North African coast. Quaternary Science Reviews 27: 2210-18.

Ramos, J., S. Domínguez-Bella, J.J. Cantillo, M. Soriguer, M. Pérez, J. Hernando, E. Vijande, C. Zabala, I. Clemente \& D. BERNAL. 2011. Marine resources exploitation by Palaeolithic hunter-fisher-gatherers and Neolithic tribal societies in the historical region of the Strait of Gibraltar. Quaternary International 239: 104-13.

VijAnde, E. 2011. La Cueva de Benzú. Aportaciones al estudio de sociedades tribales en el Holoceno, in J. Ramos, D. Bernal, A. Cabral, E. Vijande \& J.J. Cantillo (ed.) Benzú y los orígenes de Ceuta: 113-24. Ceuta: Ciudad Autónoma de Ceuta, Museo de la Basílica Tardorromana de Ceuta y Universidad de Cádiz.

Vijande, E., J. Ramos, D. Bernal, M. Pérez, I. Clemente \& D. Zurro. 2008. Cueva de Benzú (Ceuta). Nuevas aportaciones al estudio de las sociedades tribales en el área norteafricana del estrecho de Gibraltar, in M.S. Hernández Pérez, J.A. Soler Díaz \& J.A. López Padilla (ed.) IV Congreso del Neolítico Peninsular, 27-30 de noviembre de 2006, Alicante: 379-84. Alicante: MARQ, Diputación Provincial de Alicante.

Wenban-Smith, F.F., C.S. Gamble \& A.M. ApSimon. 2000. The Lower/Middle Palaeolithic site at Red Barns, Portchester, Hampshire: bifacial technology, raw material quality and the organisation of archaic behaviour. Procceedings of the Prehistoric Society 66: 209-55.

WhITE, J. 1913. The introduction to Fauna Calpensis (a natural history of Gibraltar and southern Spain). Edited by W.H. Mullens. London: The Selborne Society.

WU, R.K. \& X.R. Dong. 1985. Homo erectus in China, in R. Wu \& J.W. Olsen (ed.) Palaeoanthropology and Palaeolithic archaeology in the People's Republic of China: 79-89. Orlando (FL): Academic Press.

Received: 22 December 2011; Accepted: 13 March 2012; Revised: 2 April 2012

(C) Antiquity Publications Ltd. 